\title{
Paedagogus Hungaricus Denomination of Teachers in Hungary and Eastern Europe in the XXth Century
}

\author{
Zoltán Gloviczki \\ Faculty of Humanities and Social Sciences, Pazmany Peter Catholic University, Hungary
}

Copyright $\bigcirc 2016$ by authors, all rights reserved. Authors agree that this article remains permanently open access under the terms of the Creative Commons Attribution License 4.0 international License.

\begin{abstract}
The Hungarian word "pedagógus" means people who work as professional teachers in the educational system. Meanwhile the word "paedagogus" is a common European heritage, which is quite a unique lingual phenomenon. The paidagogos-paedagogus - across the Hellenistic culture, the Biblical use of the word, the language of the patristic age and the later theological and spiritual literature - becomes an abstraction without reference to the word of schools. The modern Indo-European languages consistently use other classical expressions (précepteur, professeur, maître etc.), or some own original words (teacher, Lehrer etc.). Though the Hungarian language has its original word covering the idea of "teacher" (tanitó); this word is getting to mean in the course of classification of professional education (by ages of pupils and types of schools) teacher, namely the one, who teaches in a secondary grammar school. Its original role has been taken over by the classical "paedagogus" (pedagógus), instead of other original Hungarian possibilities thanks to a political-historical coincidence. It is surprisingly not a direct classical heritage, but an expression used by the communist party of the new-born Soviet Union, and it was spread by the local communist parties during the Soviet occupation of Eastern Europe after the World War II.
\end{abstract}

Keywords Greek Education, Roman Education, Paidagogos, Paedagogus, Nomenclature of Teachers, Hungarian Education, Soviet Union

\section{Introduction}

Paedagogus[1]. The general use of this expression for professional teachers is a unique Hungarian, or an Eastern European phenomenon; Meanwhile the word comes from our common historical legacy. In the western civilization there is a parallel use only in Denmark, where 3-5 years in MA degree trained educators are called so, who get a degree as a kind of socio-pedagogue. They are paedagogs[2] in Danish.

The western Slavic languages have also a generalized "paedagogus" expression in line with the ones similar to Russian utschitel. These are used in the official languages for historical-political reasons, similar to Hungary.

The Hungarian version[3] of the OECD CERI[4] publication Teachers matter, which explores the international world of people affected by educational work. There is a linguistic problem which has been occupying for a long time the concerned researchers. They consider using the mirror-translation of English teacher (it exists in Hungarian - tanár -, but only expressing the teachers at ISCED 2 and ISCED 3 level) instead of the pedagógus.

This lexical question has already been mentioned in the Pedagogical Dictionary in Eleven Languages, published by F. Arato, in 1982, Budapest. The Hungarian tanitó (ISCED 1) and tanár (see above) correspond there to their exact parallels in other languages, but the identification of Hungarian pedagógus as a German Erzieher or English educator is very doubtful. The Hungarian Pedagogical Lexicon[5] mentions the problem as well, referring to the historical fact: the word pedagógus has been used from 1945 , instead of the former nevelö (educator).

Not really clear about what kind of process leading from the classical heritage to the use of pedagógus as a specialist in education; what more, to a special Hungarian or Eastern European use. The next question: How has the meaning of pedagógus covered all the person related to the very different aspects of education?

\section{Method}

We examine the development of ancient Greek word "paidagogos": its original role in the basic sources, the change of its meaning in Rome, first of all in time of appearance of Christianity, after the middle ages and renaissance. The use of paidagogos-paedagogus expression and expressions that have changed it can be found in the modern European languages including Hungarian,. This 
investigation uses the results of etymology and the dictionaries describing the actual use of different languages. Based on original sources we can review how known historical texts treat the word of education and the person of teacher, the modern theoretical works on education, from the XVIII-XXth centuries, and the use of legal and official language in acts and office texts.

\section{Results}

Our problem seems to be a special Hungarian linguistic phenomenon. After this research we can conclude a regional, and not only linguistic, but a historical result. The use of expression paedagogus (with different national spelling, pronounciation and letters) in Eastern Europe does not come from the well-known classical heritage, but is a result of impact form the political history of the XXth century.

\section{The Origins of the Expression Paidagogos}

The origin of our terminus technicus paedagogus from the ancient greek paidagogos (child-leader slave) is a commonplace. It is worth to mention that our slave-idea is usually misleading. The paidagogos in the Greek antiquity is not a part of a mass building for example pyramids, but a part of the family, who has to lead children to the school, and to protect them both physically and mentally[6]. He has to deal with all the children in the family, including even girls, who does not frequent schools[7]. He takes over the duies of nurses. $\mathrm{He}$ is expressis verbis partner and complementer of the parental education, not only outdoors, but also at home. He has a strong control over children, with even facility of corporal punishment, because he is responsible for any "incorrectness" of children[8]. This supervision and responsibility do not end at the end of child-age, they hold up to the ritual initiation to adulthood maybe later arranging an older slave for the young[9]. According to the Greek tragedies, which look into the depth of former family life, the paidagogos own the prestige in the family even across the borders of his own tasks[10].

The paidagogos - although his role is also to check the homework, or to help learning - is clearly and exactly differentiated from the teachers by both of the main classical cultures, either by Romans (praeceptor, magister), or by Greeks (didascalos). However the original meaning of this word approaches our broadest and most positive ideas of professional educator, instead of a slave.

In Rome, a slave, born at home, was from the outset in a special status, in particular one born from a freeman father (and a slave mother working around the house),was mainly from the lord of house, himself. He was taught in every case to read and write, and he accompanied the children to the school (pedisequi) [11]. Romans got to know the Greek word around the 3rd century BC. Paidagogos' of Greek origin appeared from the third Macedonian war, $168 \mathrm{BC}$. After the immigration of a huge mass of Greek slaves, the original Latin word pedisequus was entirely changed to paidagogos, although they were used side by side for a long time. The role of paedagogi (already by the Latin ortography) had gone beyond escorting and serving children for the first time, similarly that of their Greek predecessors. What is more,there was another Roman word blending into paedagogus. It was the educator/educatrix, which meant originally foster parent of waifs and strays, and its meaningchaneged later a lot.

The connection of the Roman paedagogus and teaching appeared in the independent possibility of work for the disenslaved persons. It was mainly a kind of official job, but also paedagogiums were founded in Rome. Paedagogium was not a standard school, but a training place, where the former paedagogi, already as free and well educated teachers completed the school-teaching of youngsters, first of all with different practical skills, as for agriculture or book-editing, translation etc., as needed[12].

In the age of hellenism, 4-3 century BC. The concept of paideia that meant formerly "caring for children, education", was born to a new life. The huge empires emerged after the conquests of Alexander the Great, and lived in the successor states, and Rome made an end once for all for the world of classical polis. The smaller, close communities of polis (as well as of the early Rome), with their own values, cults, dialects and traditions ceased. The paideia changed from the educational tradition of each community to the expression of all the human culture - as we better know encyclo-paideia or in latin: encyclopaedia. After-ages are wrong, when they translated this encyclopaedia as a kind of fully comprehensive education, because the Greek original meaning express just the basic education with introductory elements. Nevertheless the concept of a former "babysitter" slave has grown much richer. This process of abstraction and the role of paedagogus clearly separated from the school was put to use then by the Christian culture. The previous one appears in the New Testament, in the letter of Saint Paul to the Galatians (3.24-25.): "So the law was our guardian until Christ came that we might be justified by faith. Now that this faith has come, we are no longer under a guardian" The 'guardian' is in the original text paidagogos, as well, as the in later Latin translations, or patristic commentaries on this locus[13]. The negative mirror of this abstract use is, when Tertullian[14] supposed a "dark paedagogus" in the childhood of Socrates. The Christian tradition knows and uses at the same time the concrete child-caring role as well. Clemens of Alexandria treats it in his work "Paidagogos Christianos" (2. century AD.) as educator responsible for the religious education, of course out of official schools. An educator who knows well the secular literacy and the Christian faith as well. Saint Jerome[15] made him an example for the perfection in philosophy. 


\section{Adnomination of Teachers in Christian and Modern Europe}

Thus the Christian culture of first centuries AD. used activly both abstract and concrete meanings of paedagugus, On the other hand the authors served the secular Latin words on professional schoolmen. Saint Augustin wrote his tractat De Magistro ("On the teacher"). Cassiodorus, who later defined the standard curriculum of the middle ages, unifying the classical and christian elements of literacy, used consequently magister. The Latin Europe of the middle ages accordingly terms teachers magister and praeceptor. The word paedagogus almost entirely disappeared from treating the life of schools, but the phrase paedagogus christianus was used in spiritual education. Its last heyday was one of the most popular print of Europe of its own time, the book of Philippe d'Outreman valencian jesuit, written in 1629 and edited more than sixty times, with the same title. Paedagogus appears in the daily life of schools in only one more short period during the late renaissance. Sebald Heyden, who described most widely the word usage of school from 16th century to the end of schooling in Latin did not use this word[16], and Erasmus and Comenius took praeceptor in practical use of language - both of them used the paedagogus for a short time as the synonime, perhaps just displaying their classical erudition. The narrator of Erasmus' collection of dialogues Colloquia familiaria is a person called paedagogus, but in the dialogues themselves, where pupils discoursed with their educators, he got back to the praeceptor and magister. This interesting contradiction was solved by Erasmus in his The Praise of Folly[17], where he identified paedagogus as a person responsible for education "in a general way" - according to the Christian tradition. All the oeuvre of Comenius representing the school terminology of his age calls teachers praeceptor. In his Ianuae Linguae Latinae Vestibulum[18] encyclopedia of the use of language in schools in early modern Europe mentions the paedagogus as a synonym of the well definied praeceptor, magister and rector[19], but its meaning (paedagogus advertit et urget - "admonishes and exhorts") suggested to be out of use. This slow death of the word broaches, whether the modern use of "pedagugue" is in any relation with the classical (secular or Christian, Greek or Roman) expression.

In the English language this idea is exactly expressed by "teacher", both nowadays and from a historical point of view. None of its fifteen-sixteen living synonyms come from or is related to paedagogus). This word is different either from the word-family of paedagogus or the latin expressions of the middle ages mentionned below, but it is from the same ancient Indoeuropean root *deik-, *dik-. This root means "shows", and its oldest derivative is the Greek deiknymi, but more known is the Latin dico 3 and dico 1, surviving in "dictation", "praedication", and in several verbs of romance languages expressing "telling" or "explicating". The word developed from the original Indo-european root across the old and middle high German to the modern German zeigen (with the same meaning), and across the old English teacan and middle English techen to the modern teach, that took its recent meaning from the 9th century as a verb, and from the 13th century as a noun. The pedagogue form related to the paedagogus is known as an English word, but in its original meaning was used only by the renaissance imitating classics from the end of the 15th century, and in its "modern" meaning (person involved in theory of education) was used also mostly from the end of 14th century to the end of 17 th century[20].

As to pedagogy as an abstract noun, it does not spread at all as the heritage of any classical language, but from writings of the literate reformer Jean Calvin[21], edited in French, German and English. Its meaning concerns the theory of education and the practice as well, but its use has been short and narrow, until the 17th century. Its special derivate meaning is the place of teaching, according to the ancient paedagogium occurred from the 17th century to the 19th century[22].

The spoken French does not use the word pédagogue coming from paedagogus as a teaching person, not even as synonym[23]. Its latest active use can be detected in the 14th century, rather in a special sense (either peiorative or laudative). From that time the professeur dominates, suited by maitre and précepteur (from the Latin magister and praeceptor) mainly in belles-lettres of the 19-20th centuries. The word pédagogie, is squarely related to the theory of education, as in every western romance languages. The use of French professeur is the very same as the English teacher.

There is a similarly deep parallel between the English teacher and the German Lehrer[24] that has been used from its middle high German appearance in the 8th century (leren), trough the first German translations of the Bible and writings of Goethe with the same meaning, expressing teachers in all grades of education. Pädagog similar to French pédagogue appeared in German speaking regions in the 16th century, but its use turned out in the 18th century. Pädagoge is a modern living synonym of Lehrer, but its meaning (along with that of the abstract noun Pädagogie) has been absolutely shifted to the theoretical researcher of education.

\section{Expression of Teacher in the Hungarian Language}

The Hungarian language is a fundamentally extraordinary one in Europe. With the Finnish and Estonian, they are the three non indo-european, namely uralic or finno-ugrian languages in the continent. Hungarian tanit and words composed from it are from the most ancient, so called Uralic layer of this language[25]. The root *tuntakes its place in the semantic field of "divinator, foreteller, sorcerer" in contemporary uralic languages. But the original meaning of the verb approaches to "imitate" as well. Its reflexive and causative form (tanul, tanit) appears in the old 
Hungarian language in the 14th century with this meaning, and as a noun (tanitó - "who makes sby imitate") in the 15th century Jókai-codex[26]. Its use has been uninterrupted from that time: tanitó is who teaches. The neologism of 19th century derived the root of tanito and composed different new variants, for example from 1833 the word tanár, current but not exact parallel of teacher. The Fogarasi Dictionary explained the word as doctor working at a university, but the $A$ magyar nyelvújitás szótára (Dictionary of the Hungarian Neologies) in 1836 expanded the meaning: "person teaching in primary or secondary level, Gimnasial- und Hochschullehrer, Professor" [27]. The Czuczor-Fogarasi Dictionary wrote on tanitó: "he is, who teaches in primary school. Others, called formerly professors, are tanárs." This hardly appreciable difference has been existing in Hungarian language for almost two hundred years. Tanitó teaches in primary school, tanár in the secondary school - from the point of historical linguistic the very same words from the same root, with similar affixes - but in two "cast" of educational system.

We know the use of word paedagogus in Hungary from 1537. Its Hungarian use and ortography in the 18-19th centuries was already criticized as a germanism[28]. Older texts written in Latin used the well known magister-preceptor-doctor expressions of the European middle ages. The Hugarian words of similar meaning, mentioned above, can be referred to these ones. A fragment of a school-dictionary from Gyöngyös[29] uses the tanitó-magister parallel for teacher. Szenczi-Molnár Albert's Latin Dictionary in 1608 connected them to preceptor too. (We have to mention, he defined Latin word paedagogus the same way). The Latin dictionary of Pápai-Páriz Ferenc was very popular and edited and revised several times follows precisely his predecessor. The last representative Latin dictionary of the general use of Latin at schools Lexicon Latino-Germanico-Hungaricum of Márton József (Wien; 1818) approached to latin as to a dead language, and got out the original ancient words and meaning. It reviewed the paedagogus too, but in its original meaning: slave caring children.

\section{The Return of Paedagogus in the Modern Hungarian Language}

The first modern general lexicon "Pallas" in 1896. defines paedagogus (with Hungarian ortography pedagógus) concisely as "who cares children, educator" but the next one, Révai nagylexikon in 1922 completed the meaning: "nowadays: tanító, nevelö, tanár (teacher in primary school, teacher in secondary school, educator), and person who researches theory of education". Balassa József in his dictionary A magyar nyelv szótára (1940) defined pedagógus as a Roman slave, and as a tanitó (teacher firstly in primary school)" As if the word pedagógus could solve the problem of many different expression for different level and field of education and educators, identifying them in one word.

On the other hand the official and legal use of language tried to avoid pedagógus, as a foreign word. From the Act XIX. 1848 as late as the Act XX. 1940 tanitó and tanár were used detachedly for teacher in primary school and teacher in secondary school. From 1949 an act defined the new institute "pedagogical gymnasium" that takes up of nurses and primary teachers, and "pedagogical high school" for training of secondary teachers, but the official language kept away to use pedagógus for all of them. At the same time the Ministry of Education treated in its proposal on the training of tanárs (for all the levels of education) and the above mentioned "pedagogical high school" was changed in 1959 to a " high school for training of tanárs". A turn in this field was brought by the Act on Education 1961, that felt the very need of a complex expression for all the teaching persons, and applied the oktató, a practically unused word, that expresses very circumstantially persons, who teach.

But at the same time, the New Hungarian Lexicon representing the real and practical use of languages in 1962 used the pedagógus for the same meaning, and the first modern dictionaries of the Hungarian language edited by the Hungarian Academy of Sciences in 1972, and 1978 gave us as first meaning of pedagógus: person who teaches, and as second one: person in relation to educational research, but in 2001 there was only one meaning, the first one. The Hungarian Pedagogical Lexicon in 1978 showed the same use in its title, and in the different related entries as well. Lastly, the Act on Education 1985 Wasthe first legal document that fixed the meaning of pedagógus as an expression of all persons, who teach at any level of public education. This use had been applied since that time in both of educational acts (1993 and 2011) and related legal texts.

We can cast a glance at one more particular use of language as well. This is the modern professional pedagogical literature. Ágost Lubrich in his Általános neveléstan (General Theory of Education) [30] used consequently the nevelö-nevelés-növendék (educator, educated, education). Lajos Felméri[31], Mór Kármán[32] and István Schneller[33] apply approximately in fifty percent the paedagogus or the nevelö (educator). Ödön Weszely used pedagógus as a theoretical expert, the nevelö in general[34], like later Gyula Mitrovics[35] and Sándor Karácsony huge pedagogical oeuvre in the 1930-40s years. Neveléstan (Theory of Education) of Sándor Imre[36] in his introduction treated the problem of the variants of expressions. Ernő Fináczy in his Didaktika[37] and Lajos Prohászka's university textbook in 1937[38] moved back to the official tanitó-tanár pair of words. Two significant paper of László Nagy[39], that shows the whole organisation of education, used first the pedagógus, and then - feeling the incertitude of expressions - created some more official paraphrases for teachers[40]. We can detect finally the efforts for searching and using a general expression for teaching, and for teachers, but accordingly the pedagogical literature of the forst half of 20th century the nevelés and the nevelö (education, aducator) seems the 
most matching ones in the Hungarian language. What happened in Hungary after 1945, leading to the general use of pedagógus, to a disused and mainly forgotten classical word, instead of its potential Hungarian parallel (and what happened in Eastern Europe, where we can find the same story of the word in the same era)?

In 1945, at the end of the 2nd World War the use of Hugarian nevelo became the appropriate expression of people who teach at each level of education. It was used by researchers, by political parties, and - as far as we can reconstruct it - by the spoken language as well[41]. We find it also in the papers written by the minister responsible for the education, Géza Teleki[42]. But in 1945 with a meager national tradition but following a strong Soviet example was founded the Pedagógusok Szakszervezete (Trade Union for Teachers - called pedagógus!), that persisted in his every single publications and brochures to the use of this international word. In the Hungarian branch of the Soviet Communist Party, the Hungarian Party of Workers (former Illegal Communist Party) was bred a pedagógus-group, and a pedagógus leader group, and while the state - as we have seen before - adhered to using the traditional Hungarian words expressing teachers, the communist party followed the soviet pattern pedagógus until the main educational document of the party in 1972. Behind the scenes the pressure of communist party won the controversy of course, since the actual leadership of apparatus was in its hands from the early 1950s. The everyday use of the classical word came from this effort as well. First of all the journals and newspapers informing the teachers propagated the use of language preferred by the trade union and by the communist party. But what reason?

All these events are interesting especially as the Russian common language has used the word utschitel for teachers of all levels to this day. So we cannot suppose a kind of general Russian (Soviet) linguistic impact. Even the main pedagogical textbook representing the total mental dictature of the Soviet-era, written by Dr. Kairov[43] uses utschitel, in Hungarian translation tanitó for the teachers.

\section{Conclusions}

The strange general reuse of paedagogus and paedagogia appeared in the first half of century in official language of the Soviet Communist Party and in the sphere of education led by Nadezhda Krupskaia, wife of Vladimir Lenin, of the Soviet administration. [44]. These Two classical and quite professional-seemed expression perhaps are a compensation of a professional incompetency. Impact of this linguistic and lexicographic tendency can be detected in all the former states of Soviet occupation; but in Hungary, the words pedagógus and pedagógia got a special role because of a gap in the colloquial and academic language. The name of teachers ,from different levels and institutes, called in different ways in Hungarian language could become nevelö (educator) at the middle of the 20th century, but pedagógus, this word with so rich cultural heritage overbore it surprisingly with the help of the communist Soviet Union.

\section{REFERENCES}

[1] first version of this paper was published in Hungarian, Tanár-e a pedagógus?: Jelentéstörténeti vázlat. In: Torgyik J, editor. Sokszínű pedagógiai kultúra: II. Neveléstudományi és szakmódszertani konferencia. Nové Zámky, Szlovákia, 2014.01.09-2014.01.11. Komárno: International Research Institute; 2014. 67-72. Hungarian

[2] http://www.ug.dk/job/paedagogiskkirkeligtogsocialtarbejde/ paedagogiskarb/paedagog.aspx updated 15.04.2014. cited 15.02.2016.

[3] Ottlik A, translator. A tanárok számítanak. Budapest: Oktatási Minisztérium; 2007. Hungarian

[4] [4]Centre for Educational Research and Innovation

[5] Deák Zs, in Báthory Z, Falus I. editors. Pedagógiai lexikon. Budapest: Akadémiai Kiadó; 1997. Hungarian

[6] see Plato. Lysias, 208c, The Banquet, 183.c, Xenophon. The state of Spartans, 2.1.

[7] Plato. Lysias,223a

[8] Plato. Protagoras, 325.c-d, Laws, VII. 808 d-e, Xenophon. The state of Spartans, 3.1.

[9] Xenophon. The state of Spartans, 3.1

[10] E.g. Euripides. Ion, 725., Electra, 286-287..

[11] about him, and his followers see Quintilianus. Orator, X. 67., Horatius. Sermo 16 78., Juvenalis. Satirae X.117.

[12] see Bonner S. F. Education in Ancient Rome. Berkeley: University of Clifornia Press; 1977. 76-77.

[13] e.g. Irenaeus. 4,2,7; Augustinus. De doctrina Christiana, 3,6,10; Ambrosius. Sermones de Psalmo, CXVIII. 12,34,1.

[14] De anima, 1,4 .

[15] Hieronymus. Epistulae, 70.4.3.

[16] "Formulae puerilium colloquiorum" helped first (from1527 in several edition) the communication of Hungarian, Bohemian and Polish student at the University of Cracow

[17] 30. chapter

[18] Comenius was dealing with this problem from 1631 in a severeal form and with a several title. The text with this title was edited as the Hungarian variant (for the use of Pedagogium in Gyulafehérvár, Transsylvania) firstly in 1643, Lőcse

[19] IV. Capitulum, De rebus in schola.

[20] see Simpson J. A, Weiner E. S. C. editors. Oxford English Dictionary. 26th ed. Oxford: OUP; 1989.

[21] following mainly the L'Institution Chrétienne (originally 
Institutio Christiana) edited in Basel, 1536.

[22] Klein E. A comprehensive etymological dictionary of the English language I-II. Amsterdam - London; 1967.

[23] see e.g.. Rey A. Editor. Dictionnaire Historique de la Langue Française. Paris; 2012. French; Von Warburg, W. Franzözisches Etymologisches Wörterbuch. Tübingen; 1948. German

[24] see e.g. Kluge F. Etymologisches Wörterbuch der Deutschen Sprache. Berlin New York: DeGruyter; 1989. German

[25] Benkő L. editor. A magyar nyelv történeti etimológiai szótára I-IV. Budapest: Akadémiai Kiadó. 1967-1994. Hungarian

[26] Szarvas G, Simonyi Zs. Magyar nyelvtörténeti szótár. Budapest. 1893. Hungarian

[27] Fogarasi J. Diákmagyar műszókönyv. Pest; 1833; Szily K. A magyar nyelvújítás szótára. Budapest 1902-1908. Hungarian

[28] A magyar nyelv történeti-etimológiai szótára, see above 25.

[29] Melich, J. editor. Budapest; 1908. Hungarian

[30] 1-4. Budapest 1871. Hungarian

[31] A neveléstudomány kézikönyve. Budapest - Kolozsvár; 1890. Hungarian

[32] Faludi Sz, Jáky L. editor. Kármán Mór váltogatott pedagógiai múvei. Budapest: Tankönyvkiadó; 1969. Hungarian

[33] Pedagógiai dolgozatok. Budapest; 1900. Hungarian

[34] Pedagógia. Budapest; 1905. Hungarian

[35] A neveléstudomány alapvonalai. Debrecen-Budapest; 1933. Hungarian
[36] Budapest; 1929. Hungarian

[37] Budapest; 1935. Hungarian

[38] Az oktatás elmélete. Budapest; 1937. Hungarian

[39] Nagy célok felé. in A gyermek XII. Budapest; 1918. 382-386. Hungarian

[40] A magyar közoktatás reformja, 1918. edited by Ballai, K. Budapest; 1934. Hungarian

[41] Kardos S, Kornidesz M. Dokumentumok a magyar oktatáspolitika történetéből, 1945-1953. Budapest; 1990, 46-56. Hungarian

[42] mainly letters of the Minister sent to the Council of Public Education, and his papers in Journal for Public Education (Köznevelés) try to call teachers as an entire and integral circle. Kérelem a Miniszterelnökhöz a lap engedélyezéséhez, 1945. június 25., MM irattár Elnöki osztály 10 212/1945. in Kardos S, Kornidesz M. Dokumentumok a magyar oktatáspolitika történetéből, 1945-1953. Budapest; 1990, 26-27. Hungarian. the first issue of the Journal, 15.07.1945.

[43] Kairov. Pedagógia (originally after the 1939 version Moscow $(!), 1948)$ translated into Hungarian by Gallyas F. Budapest; 1950, mainly 486-499. XIX. chapter: A szovjet iskola tanítója.

[44] Richardson J. The Origin of Soviet Education for Librarianship: The Role of Nadezhda Konstantinovna Krupskaya (1869-1939), Lyubov' Borisovna Khavkina-Hamburger (1871-1949) and Genrietta K. Abele-Derman (1882-1954)" . Journal of Education for Library and Information Science 41 (Spring 2000): 106-128. 115-117. 